\title{
The Reciprocal Relationship Between Human Resource Management Professionalism And A Diverse South African Workplace Context
}

\author{
Nico Schutte, North-West University, South Africa \\ Nicolene Barkhuizen, North-West University, South Africa
}

\begin{abstract}
The main objective of this research was to determine the interactive relationship between human resource management (HRM) professional competencies and background variables of employees in diverse South African work place context. A Human Resource professional competency measure was administered among HR practitioners and managers $(N=483)$ from a variety of South African organisations. The results showed that significant differences exist between the respondent's perceptions of the importance of HRM competencies based on their age, educational qualifications years of work experience and management level. Respondents aged 20-29 years viewed the leadership- and personal credibility, solution creation, HR metrics, HR service delivery and HR technology as less important than older employees. Respondents with a higher level qualification viewed the HRM competencies of Leadership- and personal credibility, talent management, HR risk, HR service delivery, Strategic impact, HR business knowledge, Business acumen and HR technology as more important than respondents with a lower level qualification. Respondents with 11 to 15 years of work experience regarded the solution creation competency as more importance that did those with 0 to five years of work experience. Respondents employed on middle management level viewed the competency of being able to perform metrics as more important than did those employed on operational level. Recommendations are made.
\end{abstract}

Keywords: Competencies; Human Resource Management; Professionalism; Background Variables

\section{INTRODUCTION}

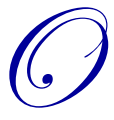
rganisations worldwide are currently experiencing a complex and dynamic changing environment in which most businesses must compete to remain sustainable. Most of these organisations realise that their competitive advantage lies within their employees (Cascio \& Boudreau, 2008; Chabault, Hulin, \& Soparnot, 2012; Collings \& Mellahi, 2009; Kaye \& Smith, 2012). Worldwide socio-economic developments such as globalisation, increasing speed towards a service economy, shorter product life cycles, changes in workforce demographics, a focus on customer loyalty, the increasing 'war for talent, and an emphasis on financial performance challenge the human resources (HR) function in its role of creating added value for the organisation (Mamman \& Sumantri, 2014; Schultz, 2010; Srimannarayana, 2010; Story, Barbuto, Luthans, \& Bovaid, 2014).

It is therefore to be expected that HR professionals should be at the forefront of organisational strategic leadership (Du Plessis \& Barkhuizen, 2011; Story et al., 2014). Yet, to the contrary, the importance of activities performed by human resource management (HRM) seems to be losing ground in the majority of organisations, while other functional areas (for example, information technology, operations, finance, and marketing) are gaining greater influence (Guest \& Woodrow, 2012). In most cases, HRM appears to be playing a secondary role, at a time when the ability to harness an organisation's HR should be more in demand and more valued than ever before (Compton, 2009). Research evidence suggests that executives uphold a narrow view of the HR function and HR practitioners (Guest \& Woodrow, 2012; Magau \& Roodt, 2010; Public Service Commission, 2010; Schultz, 2010; Venter \& Barkhuizen, 2005). In fact, there is still a prevalent typifying of the HR discipline today, which includes the 
perception is that HR functions are overstaffed, reactive, and staffed by rule-followers who insist on operating only within the parameters of policies and procedures (Guest \& Woodrow, 2012). Moreover, HR practitioners are viewed as a cost to the company that needs to be minimised to promote organisational financial performance (Becker \& Huselid, 2006).

As far back as the early seventies, Foulkes (1975) called for businesses to incorporate new social and individual values in the workplace, and highlighted the need for the HR function (personnel departments) to be more proactive, progressive, and worthy of respect. The available studies on HRM in the South African context also amplified this notion (Abbott, Goosen, \& Coetzee, 2013; Akinnusi, 2008; Barkhuizen, 2013; Barkhuizen, Goosen, van Loggerenberg \& Malan, 2009; De Bruyn \& Roodt, 2009; Du Plessis \& Barkhuizen, 2011; Ferreira, 2012; Hall \& Fourie, 2007; Kleynhans, 2006; Magau \& Roodt, 2010; Scheepers \& Schuping, 2011; Schultz, 2010; Van de Westhuizen, Van Vuuren, \& Visser, 2003; Van Vuuren \& Eiselen, 2006; Van Wyk, 2006; Van Rensburg, 2009; Van Rensburg, Basson, \& Carrim, 2011a; Van Rensburg et al., 2011b; Van Zyl \& Venier, 2006; Venter \& Barkhuizen, 2005).

To date research on the competence requirements, as well as competence models of HR practitioners in the South African context, remains scarce. Moreover no research exists on the perceived importance of HRM professional competencies of a diverse workforce in the South African context. The main objective of this research was to investigate the interactive relationship between the importance of human resource professional competencies and demographic variables in the South African context.

\section{LITERATURE REVIEW}

\section{Contextualising HRM}

The evolution of the field of HRM is well documented in literature (see Swanepoel, Van Wyk, Erasmus, \& Schenck, 2003; Van Rensburg et al., 2011a; 2011b; Venter \& Barkhuizen, 2005). Likewise, it is acknowledged by scholars and researchers that, over the course of the past three decades, people management has steadily developed to include a broader scope of functions and authority. Torrington et al. (2009) proposed that, rather than representing a revolution in people management practices, the rise of HRM signifies a progression towards a more effective practice. Similarly, Watson (2009) emphasised that HRM is not a new, or even recent, managerial or academic 'fad' or ground-breaking invention that is strange to modern circumstances. It is a profoundly sound concept that would be sensibly taken up by people in charge of any human enterprise in which work tasks are undertaken, and where there is a concern for that enterprise to continue into the future as a viable social and economic unit (pp. 8-9).

According to Lengnick-Hall et al. (2009), numerous attempts have been made to explain and define the influence of HRM in the last 30 years. Most of the studies tracked its origins back to the 1920s, in the United States of America (USA), when more liberal employers were exploring ways to achieve competitive advantage through "unity of interest [between employer and employee], cooperation and investment in labour as a human resource" (p. 64).

In the South African context, the legal, social, and political landscape changed dramatically during the 1990s, which put a lot of pressures on organisations to establish HRM practices that are aligned with a new democratic dispensation. Furthermore, South African organisations also came to realise that there is a movement from people management as a support function towards a much more strategic role, in order to attract, retain, and engage talent (Barkhuizen, 2014a). Subsequently, it led to the design of the HR- and workforce scorecards (Becker, Huselid, \& Ulrich, 2001; Huselid, Becker, \& Beatty, 2005), as well as an additional focus on the return on investment (ROI) of the HR function and its programmes (Cascio, 2000; Fitz-Enz, 2000: 2002).

In addition, since the 1990s, there has been an increased use of technology and a new belief that HRM is adding value to the organisation's product or service (Hall \& Fourie, 2007; Ulrich, 1997; 1998; Ulrich \& Brockbank, 2005; 2006). HR departments are now viewed as a strategic partner. The theoretical significance of strategic HRM stems from the resource-based view of the organisation, whereby human capital is treated as a strategic asset in improving organisational performance, in order to gain a competitive advantage (Becker \& Huselid, 2006). 
The focus of debates relating to HRM is, however, continuously changing, resulting in the progression of both academic theory and organisational expectations (Ulrich, Allen, Brockbank, Yonger, \& Nyman, 2009). It highlights the need for a proactive HR function, its crucial importance to the success of organisations, and the possibility of change in the HR function. Moreover, research clearly shows a disconnection between how far HRM has developed in becoming a profession in South African organisations and the reality of the implementation thereof. Therefore, the need exists to do in-depth analyses of the historical roots of the HRM discipline in South Africa, as it shaped current HRM practices, and will continue to do so in the future.

Below is a brief timeline that illustrates the historical development of the HRM discipline in South Africa and elsewhere. Figure 1 clearly shows how the HRM discipline evolved over the past two decades. HRM, originally termed personnel administration, materialised as a clearly defined field by the 1920 s, especially within the USA. The focus was mainly on the technical aspects of hiring, evaluating, training, and compensating employees, and was very much a staff function in most organisations. The discipline, as a general rule, did not focus on the relationships between diverse employment practices and the overall organisational performance. The discipline also lacked a unifying paradigm. Subsequently, we have seen many changes of the name for the field of HRM. The name change was the result of the global changes in social and economic movements (Kleiman, 2000; Brewster, Carey, Dowling, Grobler, Holland, \& Warnich, 2003; Jones, George, \& Hill, 2000; Fitz-enz \& Davison, 2002). 
Figure 1. Global Evolution of Human Resource Management (Researcher's own)

Fredrick Taylor develops his ideas on
scientific HR management.

Many companies establish departments devoted to maintaining the welfare of workers

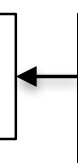

The interpretation of the Hawthorne studies begins to have an impact on management thought and practice. Greater emphasis is place on the social and informal aspects of the workplace affecting worker productivity.

In the U.S., a tremendous serge in union membership between 1935 and 1950 leads to a greater emphasis on collective bargaining and labour relations within personal management.

The civil rights movement in the U.S. reaches its peak with the passing of the Civil Rights Act of 1964.

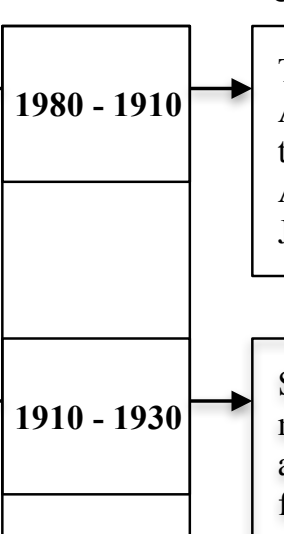

The discovery of diamonds in South Africa led to the first establishment of trade unions with in South Africa: the Amalgamated Society of Carpenters and Joinery of Great Britain.

South Africa is known for legalistic management of people, strict control, and lack of flexibility, with little room for individualism in employment relations.

Three trends dramatically impact HRM:

- diversity of the labour force;

- globalization of business and the accompanying technological revolution; and

- the focus of HRM as a strategic function.

There is an effort to establish a culture of non-racialism in South African industrial relations.

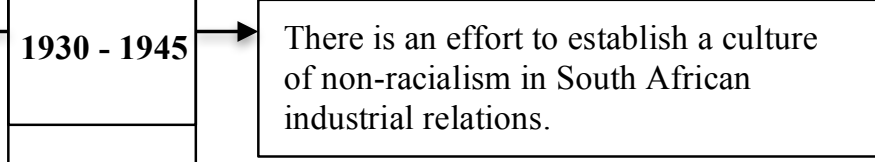

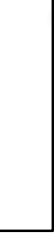

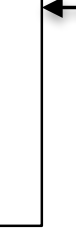

\section{.}

$1945-1965 \rightarrow$

During this time, the first personnel departments were set up within the mining industry.

During this period, South Africa gradually moved away from welfarism to human relations. 


\section{HRM Competencies and Competence Models}

Several authors have postulated that a competence-based approach to HRM is most effective in a changing the workplace (Dubois, Rothwell, Stern, \& Kemp, 2004; Gangani, McLean, \& Braden, 2006; Ulrich et al., 2009). This involves the leveraging of human capital in organisations, as opposed to the traditional job-based approach. A competence-based approach moves the focus away from jobs toward individuals and their competencies (Ulrich et al., 2009). Core competencies, or those competencies that cut across jobs, have become increasingly important as distinctions between individual jobs become more distorted, work roles change, and the environment is less stable (Byham \& Moyer, 2005; Schultz, 2010; Ulrich et al., 2008).

According to Verma, Broers, Paterson, and Schroder (2009), competencies ought to be the collective language of the HR field. They further asserted that competencies provide the dimension against which people should be assessed for readiness or capability to move into jobs, against which they should be appraised, and according to which they should be developed. According to McClelland (cited in Yusoff \& Ramayah, 2012), competencies represent the knowledge, skills, traits, attitudes, self-concepts, values, and motives directly related to job performance and important career outcomes. In addition, Noe (2002) postulated that competence models may help South African HR practitioners to improve the skills selection and efficiency level of their workforce, in order to complement changing market requirements in the midst of competitive business challenges.

The application of competence models to improve HR practitioners' skill sets is a common feature of the USA's society; however, it is not common practice in South Africa (Meyer, 2012). Authors are of the opinion that competence models developed in the USA may not be applicable to other countries, because of cultural diversity aspects (Abdullah, Musa, \& Ali, 2011; Mamman \& Sumantri, 2014). New HR competence models are thus needed, as the business world is changing at an unmatched rate. In order to stay competitive and relevant, the needed competence models must be continually researched and updated. Global economic uncertainty, technology developments, customer demands, demographic transitions, and industry mergers have led to HR issues being more important to business leaders than ever before (Hall \& Fourie, 2007). In support, Caldwell (2010) argued that competence models are perceived to be broadly effective in selecting business partners, but less effective in developing business partners or linking HR strategy with business strategy. As a result, various HR professionals and stakeholders undeniably have different views and expectations of HRM and its roles, and use different criteria to assess its effectiveness (Boudreau \& Lawler, 2014; O’ Brien, \& Linehan, 2014).

Therefore, the need exist to develop a competency model that can be applied for HR practitioners in the South African context. In the view of this, Schutte (2015) developed a HRM professional competence model that can be used to assess HR professional competencies in the South African workplace. The competence model consists of three HR professional competency dimensions: Professional behaviour and leadership, Service orientation and excellence and Business Intelligence. The Professional behaviour and leadership competency consist of four subcompetencies including Leadership- and personal credibility, Solution creation, Interpersonal communication and Innovation. The Service orientation and excellence competency include the sub-competencies Talent Management, $H R$ risk, HR metrics and HR service delivery. The Business intelligence competency includes the four subcompetencies HR strategic impact, HR business knowledge, HR business acumen and HR technology. This model has been validated and is showing promising results in terms of assessing the effective application of HR professional competencies in South African organisations.

\section{HR Competencies and Background Variables}

Limited research currently exists on employee perceptions of the importance of HRM competencies and practices in the workplace. Van der Westhuizen et al. (2003) found that the formal acknowledgement of HR as a profession is more important to men than to women. In the same study, respondents who were permanently employed in larger organisations viewed education and training as important for HRM as a profession.

A study by Masibigiri and Nienaber (2011) showed that HR practices such as utilisation of skills, career advancement, compensation, job security, and organisational leadership are important factors that will retain generation Y in the workplace. Likewise, Barkhuizen (2014b) found that HR practices such as an attractive salary, 
training and development, and opportunities for career advancement are important to attract Generation $\mathrm{Y}$ to organisations.

Job level also appears to have an important influence on how employees view HR and talent management practices. Barkhuizen and Veldsman (2012) found that middle managers perceived a poorer application of talent management practices in the organisations, compared to senior and lower-level management, and were more likely to leave the organisations as a result.

\section{RESEARCH DESIGN}

The research approach of the present study was quantitative in nature, as the aim of the research was to validate a HR competence measure. A non-experimental cross-sectional survey research strategy of inquiry was utilized in this study, based on the need for exploratory research on HR competencies in the South Africa workplace (see Field, 2009).

\section{Sampling}

The respondents were HR officers and managers from various organisations in the public and private sector who had knowledge about HRM processes in the workplace. The study employed purposive convenience sampling, whereby the respondents were chosen based on their availability to participate and to provide the desired information. Permission was obtained from the necessary authorities prior to the administration of the questionnaire. Hard-copy surveys were distributed to the relevant participants. Ethical clearance was obtained prior to the administration of the surveys. Confidentiality was maintained at all times.

A total of 800 questionnaires were distributed, of which 483 were returned. This represented a $60.38 \%$ response rate. The demographics of the respondents in this sample were as follows: $55.3 \%$ were women, $70.6 \%$ spoke indigenous languages, and $78.3 \%$ were black Africans. Of the respondents, $29.6 \%$ were aged $30-39$ years, $35.8 \%$ held a bachelor's degree as their highest level of educational qualification, and $31.1 \%$ were employed on middle management level. A total of $38.4 \%$ of the respondents had six to 15 years' work experience, $83.9 \%$ had a tenure of $0-10$ years in their current job, and $64.2 \%$ had a tenure of $0-10$ years with their current organisation.

\section{Measuring Instrument}

The HRM Professional Competence Model (Schutte, 2015) was used as a measure of HR professional competencies in the present study. This questionnaire consisted of three sections that measures three competency dimensions: Professional behaviour and leadership, Service Orientation and excellence and Business Intelligence. The Professional behaviour and leadership competency consist of four sub-competencies, namely Leadership- and personal credibility (8 items), Solution creation (4 items), Interpersonal communication (7 items), and Innovation (6 items). The Service orientation and execution competency consisted of four sub-competencies, namely Talent management (9 items), HR risk (5 items), HR metrics (6 items), and HR service delivery (6 items). The Business intelligence competency consisted of four sub-competencies, namely Strategic impact (11 items), HR business knowledge (10 items), Business acumen (6 items), and HR technology (3 items). Responses were measured in a fivepoint Likert scale, ranging from "Not important" (1) to "Critical" (5). The competency dimension measurement has been validated in the South African context (Schutte, 2015).

\section{Statistical Analyses}

Statistical analysis was carried out using the SPSS Program (SPSS, 2015). The reliability and validity of the Human resource professional competence model were determined by means of Cronbach alpha coefficients, as well as exploratory factor analysis. MANOVA was used to determine the significance of differences between the dimensions of the HRM Professional Competence Model for the demographic groups. MANOVA tests whether mean differences among groups on a combination of dependent variables are likely to have occurred by chance (Field, 2009). When an effect was significant in MANOVA, one-way ANOVA was used to discover which dependent variables had been affected. T-tests were done to assess the differences between the groups in the 
sample. For purposes of the present research, we used Cohen's (1988, p. 283) guidelines for the interpretation of effect sizes: 0.0099 constitutes a small effect, 0.0588 a medium effect, and 0.1379 is a large effect.

\section{RESULTS}

\section{Factor and Reliability Analyses}

Exploratory factor analyses, using principal component analyses and varimax rotation were done on the 36 items of the Professional behaviour and leadership competency dimension of the questionnaire. The analyses resulted in four underlying factors: Innovation (Factor 1), Leadership- and personal credibility (Factor 2), Interpersonal communication (Factor 3), and Solution creation (Factor 4) which explained $82.005 \%$ of the total variance of the competency domain.

An exploratory factor analysis, using principal components analysis and varimax rotation, was done on the 37 items of the Service orientation and execution competency dimension of the questionnaire. The analyses resulted in four underlying factors Talent management (Factor 1), HR service delivery (Factor 2), HR metrics (Factor 3), and HR Risk (Factor 4) which explained $80.677 \%$ of the total variance of the competency domain.

An exploratory factors analysis using principal components analyses and varimax rotation was done on the 44 items of the Business intelligence competency dimension of the questionnaire. The analyses resulted in four underlying factors: The four factors for both language groups were labelled Strategic impact (Factor 1), HR business knowledge (Factor 2), HR business acumen (Factor 3), and HR technology (Factor 4) which explained $77.358 \%$ of the variance of the Business intelligence competency domain.

The descriptive statistics of the competency dimensions measurements are reported in Table 1 below.

Table 1. Descriptive Statistics of the competency dimensions and sub-competencies

\begin{tabular}{|c|c|c|c|c|c|}
\hline & Mean & SD & Skewness & Kurtosis & $\alpha$ \\
\hline \multicolumn{6}{|l|}{ Professional behaviour and leadership } \\
\hline Leadership- and personal credibility & 3.989 & 0.854 & -1.015 & 0.976 & 0.959 \\
\hline Solution creation & 4.076 & 0.866 & -1.014 & 0.929 & 0.900 \\
\hline Interpersonal communication & 4.110 & 0.837 & -1.076 & 1.207 & 0.966 \\
\hline Innovation & 3.998 & 0.861 & -1.031 & 1.001 & 0.963 \\
\hline \multicolumn{6}{|l|}{ Service orientation and execution } \\
\hline Talent management & 3.838 & 0.941 & -0.888 & 0.183 & 0.966 \\
\hline HR risk & 4.035 & 0.883 & -0.890 & 0.184 & 0.940 \\
\hline HR metrics & 3.920 & 0.857 & -0.827 & 0.265 & 0.940 \\
\hline HR service delivery & 3.952 & 0.855 & -0.867 & 0.447 & 0.955 \\
\hline \multicolumn{6}{|l|}{ Business Intelligence } \\
\hline Strategic impact & 3.933 & 0.854 & -0.908 & 0.696 & 0.961 \\
\hline HR business knowledge & 4.110 & 0.809 & -1.239 & 1.817 & 0.964 \\
\hline HR business acumen & 3.891 & 0.888 & -0.915 & 0.773 & 0.951 \\
\hline HR technology & 3.988 & 0.945 & -1.098 & 0.972 & 0.923 \\
\hline
\end{tabular}

The results in Table 1 show excellent reliabilities for all the HR professional sub-competencies in line with guidelines of $\alpha \geq 0.70$ (Field, 2009). The results further show that the respondents view all HR competencies as important. The most important competencies identified were Interpersonal communication, HR business knowledge, Solution creation and HR risk.

Next, the results of the MANOVA of the differences between the importance of the dimensions of the HRM Professional Competence Model and demographic groups are reported. 


\section{MANOVA Analyses: Professional Behaviour and Leadership}

The results in Table 2 show that the respondents differed significantly on the importance of Professional behaviour and leadership, based on the variables home language, ethnicity, age, qualifications, and years of work experience. No significant differences were found according to the variables gender, job level, years in current job, and years in current organisation. Further post hoc analyses showed no significant differences according to home language and ethnicity. The remainder of the post hoc analyses results is reported below.

Table 2. Manova Analyses - Professional behaviour and leadership and Demographic Groups

\begin{tabular}{|c|c|c|c|c|c|c|}
\hline & Value & $\mathbf{F}$ & Hypothesis df & Error df & $p$ & Partial eta squared \\
\hline Gender & .997 & $.347^{\mathrm{b}}$ & 4.000 & 475.000 & .846 & .003 \\
\hline Home language & .030 & $3.639^{\mathrm{b}}$ & 4.000 & 477.000 & $.006 *$ & .030 \\
\hline Ethnicity & .932 & 2.787 & 12.000 & 1246.440 & $.001 *$ & .023 \\
\hline Age & .936 & 2.247 & 12.000 & 1063.884 & $.008 *$ & .022 \\
\hline Qualification & .934 & 2.645 & 12.000 & 1222.629 & $.002 *$ & .022 \\
\hline Job level & .957 & 1.282 & 16.000 & 1399.851 & .200 & .011 \\
\hline Years' work experience & .925 & 1.541 & 24.000 & 1640.844 & $.046 *$ & .019 \\
\hline Years in current job & .975 & $1.543^{\mathrm{b}}$ & 8.000 & 952.000 & .138 & .013 \\
\hline Years in current organisation & .987 & $.756^{\mathrm{b}}$ & 8.000 & 948.000 & .642 & .006 \\
\hline
\end{tabular}

* Significant differences

Wilks's lambda for the variable age was $\left..936 F_{(12,483)}=2.247 ; p \leq 0.05\right]$. Analysis of each dependent variable, using a Bonferroni adjusted alpha level of 0.025 , showed that the age groups differed in terms of Leadership-and personal credibility $\left[F_{(3,483)}=2.773 ; p \leq 0.05 ;\right.$ partial $\left.\eta^{2}=.020\right]$, and Solution generation $\left[F_{(3,483)}=5.838 ; p \leq 0.05\right.$; partial $\left.\eta^{2}=.041\right]$. Respondents aged 20-29 years viewed the leadership- and personal credibility competency as less important than those aged 30-39 years. Respondents aged 20-29 viewed the competency of solution generation as less important than respondents aged 30-39 years and 40-49 years. The effects were small.

Wilks's lambda for the variable qualification was $.934\left[F_{(12.483)}=2.645 ; p \leq 0.05\right]$. Analysis of each dependent variable, using a Bonferroni adjusted alpha level of 0.025 , showed that the groups differed in terms of Leadershipand personal credibility $\left[F_{(3,483)}=5.245 ; p \leq 0.05 ;\right.$ partial $\left.\eta^{2}=.033\right]$, Solution generation $\left[F_{(3,483)}=5.653 ; p \leq 0.05\right.$; partial $\left.\eta^{2}=.035\right]$, Interpersonal communication $\left[F_{(3,483)}=3.988 ; p \leq 0.05 ;\right.$ partial $\left.\eta^{2}=.025\right]$, and Innovation $\left[F_{(3,}\right.$, 483) $=4.322 ; p \leq 0.05$; partial $\left.\eta^{2}=.027\right]$. The results showed that respondents with a postgraduate qualification viewed the leadership- and personal credibility competency as more important than did respondents with a diploma or bachelor's degree as their highest level of qualification. Respondents with a bachelor's degree viewed the competencies of solution creation, interpersonal communication, and innovation as more important than did those with a diploma as their highest level of qualifications. The effects were small.

Wilks's lambda for the variable years of work experience was $.925\left[F_{(12,483)}=1.541 ; p \leq 0.05\right]$. Analysis of each dependent variable, using a Bonferroni adjusted alpha level of 0.025 , showed that groups differed regarding Solution creation $\left[F_{(6,483)}=2.329 ; p \leq 0.05\right.$; partial $\left.\eta^{2}=.029\right]$. Those who had 11 to 15 years of work experience regarded the solution creation competency as more importance that did those with 0 to five years of work experience.

\section{MANOVA Analyses: Service Orientation and Execution}

The results in Table 3 show that the respondents differed significantly regarding the importance of Service orientation and execution, based on the variables home language, age, qualifications, and job level. No significant differences were found with reference to the variables gender, ethnicity, years of work experience, years in current job, or years in current organisation. Further post hoc analyses showed no significant differences according to the variables home language and ethnicity. The remainder of the results of the post hoc analyses is reported below. 
Table 3. Manova Analyses - Service orientation and execution and Demographic Groups

\begin{tabular}{l|c|c|c|c|c|c}
\hline & Value & F & Hypothesis df & Error df & $p$ & Partial eta squared \\
\hline Gender & .973 & $3.244^{\mathrm{b}}$ & 4.000 & 475.000 & .012 & .027 \\
\hline Home language & .963 & $4.554^{\mathrm{b}}$ & 4.000 & 477.000 & $\mathbf{. 0 0 1}$ & .037 \\
\hline Ethnicity & .958 & 1.682 & 12.000 & 1246.440 & .065 & .014 \\
\hline Age & .947 & 1.828 & 12.000 & 1063.884 & $\mathbf{. 0 4 0}$ & .018 \\
\hline Qualification & .921 & 3.220 & 12.000 & 1222.629 & $\mathbf{. 0 0 0}$ & .027 \\
\hline Job level & .938 & 1.857 & 16.000 & 1399.851 & $\mathbf{. 0 2 0}$ & .016 \\
\hline Years' work experience & .939 & 1.245 & 24.000 & 1640.844 & .191 & .016 \\
\hline Years in current organisation & .989 & $.664^{\mathrm{b}}$ & 8.000 & 952.000 & .723 & .006 \\
\hline Years in current job & .987 & $.773^{\mathrm{b}}$ & 8.000 & 948.000 & .626 & .006 \\
\hline
\end{tabular}

Wilks's lambda for the variable age was $.947\left[F_{(12.483)}=1.828 ; p \leq 0.05\right]$. Analysis of each dependent variable, using a Bonferroni adjusted alpha level of 0.025 , showed that the groups differed regarding $H R$ risk $\left[F_{(3,483)}=\right.$ 4.213; $p \leq 0.05 ;$ partial $\left.\eta^{2}=.030\right]$, HR metrics $\left[F_{(3,483)}=4.163 ; p \leq 0.05 ;\right.$ partial $\left.\eta^{2}=.030\right]$, and HR service delivery $\left[F_{(3,483)}=3.708 ; p \leq 0.05\right.$; partial $\left.\eta^{2}=.027\right]$. Respondents aged 20-29 years viewed $H R$ risk as less important than did those aged 30-39 years. Respondents aged 20-29 years viewed HR metrics and HR service delivery as less important than did respondents aged 30-39 years and 40-49 years.

Wilks's lambda for the variable qualification was $.921\left[F_{(12,483)}=3.220 ; p \leq 0.05\right]$. Analysis of each dependent variable, using a Bonferroni adjusted alpha level of 0.025 , showed that the groups differed regarding Talent management $\left[F_{(3,483)}=7.129 ; p \leq 0.05 ;\right.$ partial $\left.\eta^{2}=.053\right]$, HR risk $\left[F_{(3,483)}=3.452 ; p \leq 0.05 ;\right.$ partial $\left.\eta^{2}=.029\right], H R$ metrics $\left[F_{(3,483)}=4.513 ; p \leq 0.05\right.$; partial $\left.\eta^{2}=.040\right]$, and HR service delivery $\left[F_{(3,483)}=4.473 ; p \leq 0.05 ;\right.$ partial $\eta^{2}=$ .040]. The results showed that respondents with a postgraduate qualification or a bachelor's degree viewed the talent management competency as more important than did those with a certificate or diploma as their highest qualification. Respondents with a bachelor's degree viewed the competencies of governance and HR service delivery as more important than did those with a certificate or diploma as their highest level of qualification. Respondents with a postgraduate qualification viewed the HR service delivery competency as more important than did respondents in possession of a bachelor's degree as their highest level of qualification.

Wilks's lambda for the variable job level was $.938\left[F_{(16,483)}=1.857 ; p \leq 0.05\right]$. Analysis of each dependent variable, using a Bonferroni adjusted alpha level of 0.025 , showed that the groups differed regarding HR metrics $[F$ $(4,483)=2.715 ; p \leq 0.05$; partial $\eta^{2}=.023$. Respondents employed on middle management level viewed the competency of being able to perform metrics and measurements as more important than did those employed on operational level.

\section{MANOVA Analyses: Business Intelligence Dimension}

The results in Table 4 show that the respondents differed significantly regarding the importance of Business intelligence, based on age and qualifications. No significant differences were found for the variables gender, home language, ethnicity, job level, years of work experience, years in current job, or years in current organisation. The results of the post hoc analyses are reported below.

Table 4. Manova Analyses - Business Intelligence and Demographic Groups

\begin{tabular}{l|c|c|c|c|c|c}
\hline & Value & F & Hypothesis df & Error df & $\boldsymbol{p}$ & Partial eta squared \\
\hline Gender & .992 & $.923^{\mathrm{b}}$ & 4.000 & 473.000 & .450 & .008 \\
\hline Home language & .997 & $.310^{\mathrm{b}}$ & 4.000 & 475.000 & .872 & .003 \\
\hline Ethnicity & .983 & .664 & 12.000 & 1241.149 & .787 & .006 \\
\hline Age & .933 & 2.336 & 12.000 & 1058.592 & $\mathbf{. 0 0 6}$ & .023 \\
\hline Qualification & .938 & 2.481 & 12.000 & 1217.337 & $\mathbf{. 0 0 3}$ & .021 \\
\hline Job level & .949 & 1.493 & 16.000 & 1393.741 & .094 & .013 \\
\hline Years' work experience & .945 & 1.106 & 24.000 & 1633.867 & .328 & .014 \\
\hline Years in current organisation & .969 & $1.893^{\mathrm{b}}$ & 8.000 & 948.000 & .058 & .016 \\
\hline Years in current job & .983 & $.989^{\mathrm{b}}$ & 8.000 & 944.000 & .443 & .008 \\
\hline
\end{tabular}


Wilks's lambda for the variable age was $\left..933 F_{(12.483)}=2.336 ; p \leq 0.05\right]$. Analysis of each dependent variable, using a Bonferroni adjusted alpha level of 0.025 , showed that the groups differ regarding $H R$ technology $\left[F_{(3,483)}=\right.$ 4.322; $p \leq 0.05$; partial $\left.\eta^{2}=.031\right]$. Respondents aged 20-29 years viewed HR technology as less important, compared to those aged 30-39 years. Respondents aged 20-29 viewed HR technology as less important, compared to respondents aged 30 to 39 years.

Wilks's lambda for the variable qualification was $.921\left[F_{(12.483)}=3.220 ; p \leq 0.05\right]$. Analysis of each dependent variable, using a Bonferroni adjusted alpha level of 0.025, showed that the groups differ regarding Strategic impact $\left[F_{(3.483)}=4.243 ; p \leq 0.05 ;\right.$ partial $\left.\eta^{2}=.037\right]$, HR business knowledge $\left[F_{(3.483)}=3.220 ; p \leq 0.05 ;\right.$ partial $\eta^{2}=$ $.032]$, HR business acumen $\left[F_{(3.483)}=3.185 ; p \leq 0.05 ;\right.$ partial $\left.\eta^{2}=.026\right]$, and HR technology $\left[F_{(3.483)}=3.695 ; p \leq\right.$ 0.05 ; partial $\left.\eta^{2}=.027\right]$. The results showed that respondents with a postgraduate qualification viewed Strategic impact, HR business knowledge, Business acumen, and HR technology as more important, compared to respondents in possession of a diploma as their highest level of educational qualification.

\section{DISCUSSION}

The main objective of this research was to determine the interactive relationship between the application of professional human resource management competencies and employees based on their demographic characteristics. In general the results highlighted the importance of human resource management competencies in the workplace. HR Business Knowledge, interpersonal skills and communication, HR solutions and implementation and HR risk emerged as the most important HR competencies. These results amplified the need for core HR competencies in an unstable business environment (Schultz, 2010; Ulrich et al., 2008).

The MANOVA analyses showed significant differences between the respondents' perceptions of HR competencies based on their demographic characteristics. The predominant was that Generation Y employees view HR competencies as less important, compared to older generations. In the present study, respondents aged 20-29 years viewed Solution generation, HR metrics, HR service delivery, and HR technology as less important, compared to respondents aged 30-39 years and 40-49 years. These results contradict previous findings that younger generations view HR competencies as more important than other age groups (Barkhuizen, 2014; Masibigiri \& Nienaber, 2011). These results are concerning, as younger generations display faster employment turnover than older generations.

The results further showed that employees with a higher-level qualification viewed the competencies Leadershipand personal credibility, Solution creation, Interpersonal communication, Innovation, HR risk, HR service delivery, Strategic impact, HR business knowledge, Business acumen, and HR technology as more important, compared to employees with a lower-level qualification. Furthermore, respondents on middle management level viewed $H R$ metrics as more important than did those employed on operational level. Finally, those who had 11 to 15 years of work experience regarded Solution creation as more important that did those with 0 to five years' work experience. The results confirm previous findings that employees in higher ranks in organisations and with more years of work experience regard HR practices as more important, compared to those on lower organisational levels (Barkhuizen \& Veldsman, 2012).

This research had some limitations. A first limitation was the sample size, specifically the sampling procedure in the present study, which has limitations in terms of the findings generalised to the total population. Secondly limited empirical information exists on the interactive relationship between professional human resource management competencies and background variables which made interpretation of the results difficult. For future research it is recommended that the sample be expanded to other occupational groups to allow for the generalisation of research results. More research is also needed to clarify human resource management competencies within the South African and global fraternity.

In conclusion, this research highlighted the importance of human resource management as a profession in South Africa and the subsequent application of professional competencies. HR practitioners should therefore focus on improving their status as a strategic business partner and enhance the transparent application of HR competencies across all demographic groups in the workplace. Based on the results of this research more emphasis should be 
placed on educating younger generations on the importance of human resource management and professionalism in the workplace.

\section{AUTHOR BIOGRAPHIES}

Nico Schutte is an Associate Professor at the Department of Public Administration, North-West University. He has published extensively in the field of strategic leadership and talent management. Nico has also been the CEO of various consulting companies specialising in leadership development and coaching. This article is based on his second PhD in Industrial Psychology.

Nicolene Barkhuizen is a Full Professor Research of the Faculty of Commerce and Administration, North-West University. She is also the leader of the talent management research programme at North-West University which is currently the front-runner in talent management research in Southern Africa. Nicolene has published extensively in this field.

\section{REFERENCES}

Abbott, P., Goosen, X., \& Coetzee, J. (2013). The human resource function contribution to human development in South Africa. SA Journal of Human Resource Management/SA Tydskrif vir Menslikehulpbronbestuur, 11(1), 1-14.

Akkinusi, D. M. (2008). Benchmarking of human resource management in the public sector: Prospects, problems and challenges. South African Journal of Human Resource Management, 6(2), 25-31.

Barkhuizen, E.N. (2013). Filling the Knowledge gap: How Relevant is University Programmes to Industry Needs? In B. Janiunaite \& M. Petraite (eds.) $14^{\text {th }}$ European Conference on Knowledge Management, Kaunas, Lithuania, pp.17-24. ISBN: 978-1-909507-40-1

Barkhuizen, E.N. (2014a). How relevant is Talent Management in Local Government Institutions? Mediterranean Journal of Social Sciences, 5(20), 2223-2230.

Barkhuizen, E.N. (2014b). Exploring the Importance of Rewards as a Talent Management Tool for Generation Y Employees. Mediterranean Journal of Social Sciences, 5(27), 1100-1105.

Barkhuizen, E. N., Goosen, X., Van Loggerenberg, E., \& Malan, B. (2009). Rethinking undergraduate curricula in comprehensive universities: A South African case study. Paper published in the peer reviewed conference proceedings of the London International Conference on Education, pp. 178-184, Infonomics Society, ISBN 978-0-9564263-0-7.

Barkhuizen, E. N., \& Veldsman, G. (2012, July). The impact of talent management practices on the retention of employees in an electricity supply company. Poster presented at the $30^{\text {th }}$ International Congress of Psychology, Cape Town.

Becker, B. E., Huselid, M. A., \& Ulrich, D. (2001). The HR scorecard: Linking people, strategy and performance. Boston: Harvard Business School Press.

Becker, B. E., \& Huselid, M. A. (2006). Strategic human resources management: Where do we go from here? Journal of Management, $32(6)$.

Brewster, C., Carey, L., Dowling, P., Grobler, P., Holland, P., \& Warnich, S. (2003) Contemporary issues in human resource management: Gaining a competitive advantage ( $2^{\text {nd }}$ ed.). Oxford University Press, South Africa, Cape Town, IBSN 0 415 42392-9.

Boudreau, J., \& Lawler, E. E. (2014). Stubborn traditionalism in HRM: Causes and consequences. Human Resource Management Review, 24, 232-244.

Byham, W. C., \& Moyer, R. P. (2005). Using competencies to build a successful organization [monograph]. Retrieved May 7 , 2009, from 100 Development Dimensions International, Inc.: Competency management — a practitioners guide.

Caldwell, R. (2008). HR business partner competencies models: Recontextualising effectiveness. Human Resource Management Journal, 18(3), 275-294.

Cascio, W. F. (2000). Costing human resources: The financial impact of behaviour in organizations ( $4^{\text {th }}$ ed.). Boston, MA: Kent.

Cascio, W. F., \& Boudreau, J. W. (2008). Investing in people: Financial impact of human resource initiatives. Upper Saddle River: Pearson Education.

Chabault, D., Hulin, A., \& Soparnot, R. (2012). Talent management in clusters. Organisational Dynamics, 41, 327-335.

Collings, D., \& Mellahi, K. (2009). Strategic talent management: A review and research agenda. Human Resource Management Review, 19, 304-313.

De Bruyn, L., \& Roodt, G. (2009). Applying the criteria of Ulrich and Brockbank for the assessment of the role of human resources as a strategic business partner in a mining company. SA Journal of Human Resource Management, 7(1), 111. 
Du Plessis, Y., \& Barkhuizen, E. N. (2011). The strategic role of human resource professionals in a South African context. Paper presented at the European Association for Work and Organisational Psychology Conference, Maastricht, Netherlands, 25-28 May.

Dubois, D. D., Rothwell, W. J., Stern, D. J., \& Kemp, L. K. (2004). Competency-based human resource management. Palo Alto, CA: Davies-Black Publishing.

Ferreira, N. (2012). Hardiness in relation to organisational commitment in the human resource management field. SA Journal of Human Resource Management/SA Tydskrif vir Menslikehulpbronbestuur, 10(2), 1-10.

Cohen, J. (1988). Statistical power analysis for the behavioral sciences $\left(2^{\text {nd }}\right.$ ed.). Orlando, FL: Academic Press.

Foulkes, F. K. (1975). Future of human resources. Harvard Business Review (March-April), 5-18.

Fitz-enz, J., \& Davison, B. (2002). How to measure human resources management. New York, NY: McGraw Hill Education.

Gangani, N., McLean, G. N., \& Braden, R. A. (2004). A competency-based human resource development strategy. Performance Improvement Quarterly, 19(1), 127-139.

Guest, D. E., \& Woodrow, C. (2012). Exploring the boundaries of human resource managers' responsibilities. Journal of Business Ethics, (111), 109-119.

Hall, C., \& Fourie, L. (2007). Exploring the role of the human resource function in the South African information technology industry. South African Journal of Human Resource Management, 5(1), 54-64.

Huselid, M. A., Becker, B. E., \& Beatty, R. W. (2005). The Workforce Scorecard: Managing human capital to execute strategy. Boston: Harvard Business School Press.

Jones, G. R., George, J. M., \& Hill, C. W. L. (2000). Contemporary management (2 ${ }^{\text {nd }}$ ed.). Boston, MA: Irwin McGraw-Hill.

Kaye, B., \& Smith, C. P. (2012). Career development: Shifting from nicety to necessity. Training \& Development: 52-55.

Kleiman, L. (2000). Human resource management: A managerial tool for competitive advantage ( $2^{\text {nd }}$ ed.). Cincinnati, $\mathrm{OH}$ : South-Western College Publishing.

Kleynhans, E. P. J. (2006). The role of human capital in the competitive platform of South African industries. South African Journal of Human Resource Management, 4(3), 55-62.

Lengnick-Hall, M. L., Lengnick-Hall, C. A., Andrade, L. S., \& Drake, B. (2009). Strategic human resource management: The evolution of the field. Human Resource Management Review, 19, 64-85

Magau, M. D., \& Roodt, G. (2010). An evaluation of the Human Capital Bridge ${ }^{\mathrm{TM}}$ framework. SA Journal of Human Resource Management/SA Tydskrif vir Menslikehulpbronbestuur, 8(1), 1-10.

Mamman, A., \& Somantri, Y. (2014). What role do HR practitioners play in developing countries: an exploratory study in an Indonesian organization undergoing major transformation. The International Journal of Human Resource Management, 25(11), 1567-159

Masibigiri, V., \& Nienaber, H. (2011). Factors affecting the retention of Generation X public servants: An exploratory study. SA Journal of Human Resource Management/SA Tydskrif vir Menslikehulpbronbestuur, 9(1), 1-11.

Noe, R. A. (2002). Employee training and development. McGraw-Hill/Irwin.

O'Brien, E., \& Linehan, C. (2014). A balancing act: Emotional challenges in the HR roles. Journal of Management Studies, 51, 1257-1285.

Public Service Commission. (2010). Assessment of the state of Human resource management in the public service. Red Flag Design \& Marketing Publishers, South Africa.

Scheepers, C., \& Shuping, J. (2011). The effect of human resource practices on psychological contracts at an iron ore mining company in South Africa. SA Journal of Human Resource Management/SA Tydskrif vir Menslikehulpbronbestuur, 9(1), 1-19.

Schultz, C. M. (2010). HR competencies at a merged higher education institution. South African Journal of Human Resource Management, 8(1), 1-8.

Schutte, N. E. (2015). The development of a human resource management competency measure: A pilot study. Unpublished research paper.

Srimannarayana, M. (2010). Human resource roles in India. The Indian Journal of Industrial Relations, 46(1), 88-99.

Story, J. S. P., Barbuto, J. E., Jr, Luthans, F., \& Bovaird, J. A. (2014). Meeting the challenges of effective international HRM: Analyses of the antecedents of global mindset. Human Resource Management, 53(1), 131-155.

Swanepoel, B. J., Erasmus, B. J., Van Wyk, M. W., \& Schenk, H. W. (2003). South African human resource management: Theory and practice ( $3^{\text {rd }}$ edition). South Africa: Juta \& Co Ltd.

SPSS Inc. (2015). SPSS 22.0 for Windows. Chicago, IL: Author.

Torrington, D., Hall, L., Taylor, S., \& Atkinson, C. (2009). Fundamentals of human resource management: Managing people at work. Harlow: Pearson Education.

Ulrich, D. (1997). Human resource champions: The next agenda for adding value and delivering results. Boston: Harvard Business School Press.

Ulrich, D. (1998). Delivering results: A new mandate for human resource professionals. Boston: Harvard Business School Press.

Ulrich, D., \& Brockbank, W. (2005). The HR value proposition. Boston: Harvard Business School Press.

Ulrich, D., \& Brockbank, W. (2006). Building sustainable value through your HR proposition. Conference proceedings of Global Leaders, 22 February 2006. Midrand, South Africa: Gallagher Estate. 
Ulrich, D., Allen, J., Brockbank, W., Yonger, J., \& Nyman, M. (2009). HR transformation: Building human resources from the outside in. New York: McGraw-Hill/RBL Institute.

Van der Westhuizen, C., van Vuuren, L. J., \& Visser, D. (2003). Human resource management in South Africa: Practitioners perspectives. South African Journal of Human Resource Management, 1(2), 1-12.

Van Rensburg, A. H. (2009). Human resource management as a profession in South Africa. Unpublished MPhil dissertation, University of Pretoria, Pretoria.

Van Rensburg, H., Basson, J. S., \& Carrim, N. M. H. (2011a). The establishment and early history of the South African Board For People Practices (SABPP) 1977-1991. SA Journal of Human Resource Management/SA Tydskrif vir Menslikehulpbronbestuur, 9(1), 1-12.

Van Rensburg, H., Basson, J., \& Carrim, N. (2011). Human resource management as a profession in South Africa. SA Journal of Human Resource Management/SA Tydskrif vir Menslikehulpbronbestuur, 9(1), 1-15.

Van Vuuren, L. J., \& Eiselen, R. J. (2006). A role for HR in corporate ethics? South African practitioners' perspectives. South African Journal of Human Resource Management, 4(3), 22-28.

Van Wyk, C. D. W. (2006). Human resource practitioners' perceptions of their role and responsibility in managing HIV/AIDS in industry. South African Journal of Human Resource Management, 4(3), 29-35.

Van Zyl, G., \& Venier, P. (2006). Compilation of an econometric human resource efficiency model for project management best practices. South African Journal of Human Resource Management, 4(3), 44-47.

Venter, A., \& Barkhuizen, E. N. (2005). Rethinking undergraduate curricula: A Delphi study of human resource management and industrial and organisational psychology. Journal of Industrial Psychology, 31, 46-53.

Verma, S., Broers, T., Paterson, Schroder, C., Medves, J. M. et al. (2009). Core competencies: The next generation. Comparison of a common framework for multiple professions. Journal of Applied Health, 38(1), 47-53.

Watson, T. (2009). Organisations, strategies and human resourcing. In J. Leopold, and L. Harris (Eds.), The strategic managing of human resources $\left(2^{\text {nd }}\right.$ ed.). Harlow FT Prentice Hall.

Yusoff, Y. M., \& Ramayah, T. (2012). Validity and reliability of the Human Resource Competencies Scale. World Applied Sciences Journal $16(1)$ : 94-98. 


\section{NOTES}

